\title{
The mediator role of the use of emotion in the association between personality traits and workaholism
}

\author{
İlknur Sayan*
}

Istanbul Kent University, Healthcare Management, Faculty of Health Sciences, Istanbul (Turkey).

\begin{abstract}
Título: El papel mediador del uso de la emoción en la asociación entre rasgos de personalidad y adicción al trabajo.

Resumen: Este estudio examinó el papel mediador del componente de uso de la emoción (UoE), de la Escala de inteligencia emocional, en la relación entre extraversión (EX) y conciencia dentro de los Cinco Grandes factores de personalidad, y las dimensiones de trabajar en exceso (WE) y trabajar compulsivamente de la Escala holandesa de adicción al trabajo. Junto con este objetivo, se recopilaron datos del personal sanitario, en su mayoría enfermeras, que trabajaba en hospitales privados que prestan servicios en Estambul. Los hallazgos indicaron que WE tuvo un efecto directo no significativo sobre $\operatorname{EX}(\beta=-0.358 ; p>.05)$, mientras que el efecto indirecto de WE sobre EX a través de UoE fue significativo $(\beta=0.147 ; p<.05)$. Este estudio revela que UoE actúa como un mediador completo en el efecto de WE sobre EX.

Palabras clave: Rasgos de personalidad. Big Five. Adicción al trabajo. Trabajar en exceso. Trabajar compulsivamente. Uso de la emoción.
\end{abstract}

\section{Introduction}

Workaholism is closely associated not only with the positive outputs like work enjoyment and psychological well-being but also with negative outcomes such as work-life imbalance, work addiction and psychological distress (Jackson et al., 2016). The working world today is not what it was 40 years ago. Especially in Western cultures, individuals today are generally staying at work later, working longer workweeks and bringing their work home (Aziz \& Tronzo, 2011). Sometimes, people invest heavy time in work in order to meet their increasing needs, escape from daily problems and achieve success or advancement, or due to many other reasons. This excessive obsession is defined as 'workaholism' (Snir \& Zohar, 2008). In addition to this, workaholics are perfectionists and they find it difficult to delegate tasks although they tend to be fairly productive (Aziz \& Tronzo, 2011).

Workaholic is a term used to describe individuals who are addicted to work. Even if we cannot define workaholism in all aspects, we can state that it causes negative behaviours and health consequences. According to some authors, it can lead to harmful consequences such as fatigue, stress and physical or mental health problems (Burke, 2000). Some authors alleged that workaholism can lead to negative consequences like job burnout, exhaustion, stress and physical and psychological health problems (Burke, 2000). In support of that, Robinson (2000) marked that workaholism 'may result

* Correspondence address [Dirección para correspondencia]:

İlknur Sayan. E-mail: ilknur-sayan@hotmail.com

(Article received: 21-10-2020, revised: 01-12-2020, accepted: 01-12-2020)
Abstract: This study examined the mediator role of use of emotion (UoE) component of the emotional intelligence Scale in the relationship between extraversion $(\mathrm{EX})$ and conscientiousness within the Big Five personality factors, and the dimensions of working excessively (WE) and working compulsively of the Dutch Work Addiction Scale. Along with this aim, data were collected from healthcare staff, most of who were nurses, working at private hospitals serving in Istanbul. The findings indicated that WE had a non-significant direct effect on $\operatorname{EX}(\beta=-0.358 ; p>.05)$, while the indirect effect of WE on EX through $\mathrm{UoE}$ was significant $(\beta=0.147 ; p<.05)$. This study reveals that $\mathrm{UoE}$ acts as a full mediator in the effect of WE on EX.

Keywords: Personality traits. Big Five. Workaholism. Working excessively. Working compulsively. Use of emotion. in unmanageable life, family disintegration, serious health problems and even death'. Some people commit much more time and energy to their working lives (Snir \& Zohar, 2008). However, it is difficult to find reliable statistics concerning the prevalence of workaholism. It was estimated that workaholism was more common among some work groups, especially among medicians (Griffiths, 2005). When it is considered that workaholism can constitute the most of an individual's life, it is thought to lead to an unavoidable anxiety which adversely affects the interpersonal and social functioning, danger to the health, lower work quality and harmful effect on family life and organisation (Snir \& Zohar, 2008).

Concerning the harmful effects, there has been extensive research which revealed that there were negative consequences of workaholism on individuals and organisations. In this study, workaholism is treated as a concept leading to undesired outcomes (Schaufeli et al., 2006). Additionally, it was found out that there was limited research on workaholism where it is treated as a personality trait, and on the relationship between workaholism and personality traits (Snir \& Zohar, 2008). Working life is not independent of emotions. The use of emotions (UoE) plays an important role in human behaviour (Gedizler, 2010). The ability to use emotions includes how emotion is used and how it affects the thinking process or cognition to help problem-solving. Emotions can act as mechanisms leading to thinking (Caruso \& Salovey, 2004). In individuals who exhibit workaholic attitudes and behaviour, the UoEs can help individuals protect themselves from the harmful consequences of workaholism.

The conscientiousness (CO) dimension includes subjects of perseverance, work, motivation, patience and the determination level in reaching the goal in the working life of the 
individual (Tozkoparan, 2013). Since the dimension of CO affects many issues, its effect on workaholism has been found worth examining. In addition to being energetic and sociable, the extraversion (EX) personality dimension has also been associated with high levels of positive emotions, seeking experience and success and high job satisfaction (Burke et al., 2006). For example, Burke et al. (2006) found that EX was about enjoying work. Therefore, it was predicted that the EX personality trait might be related to workaholics.

Furthermore, healthcare staff were purposefully selected as participants to increase the significance of the study as they are recognised to work intensively due to the nature and scope of their job. Workaholism can lead to many unfavourable consequences like job burnout, stress, anxiety, and lack of timely and correct decision-making (Clark et al, 2016). Although there have been considerable research conducted to examine the relationship between workaholism and personality traits, none of them specifically focused on the mediating role of the $\mathrm{UoE}$ in that relationship; considering the increasing number of workaholics and the negative consequences of workaholism on individuals, it was believed that there was much more need to devote research on the association between personality factors and workaholism, and the role of UoE as a mediator. In the present study, we contribute to a better understanding of the interpersonal and organisational consequences of workaholism by investigating it with workplace UoE. Working life is not independent of emotions. The use of emotions has an important role in human behavior. (Gedizler 2010) The ability to use emotions (Peter, 2010) includes how emotion is used and how it affects the thinking process or cognition to aid problem solving. Emotions can act as mechanisms that lead to thinking (Caruso \& Salovey, 2004). The use of emotions can enable the individual to serve their purposes (Yurtbasi, 2018). In individuals who exhibit workaholic attitudes and behavior, the use of emotions can help individuals to control their emotions and protect themselves from the harmful consequences of workaholicism.

Conscientiousness dimension includes subjects of perseverance, study, motivation, patience and determination level in reaching the goal in the working life of the individual (Tozkoparan, 2013). Since the dimension of conscientiousness affects many issues, its effect on workaholicism has been found worth examining.

In addition to being energetic and sociable, the extraversion personality dimension has also been associated with high levels of positive emotions, seeking experience and success, and high job satisfaction (Burke et al.2006). For example, Burke et al. (2006) found that Extraversion is about enjoying work. Therefore, it was predicted that the extraversion personality trait might be related to workaholics In addition, working excessively (WE) and compulsively brings about many problems for the modern-day individuals, as nowadays emotional intelligence (EI) has gained ground and people need to communicate more effectively and construct more professional relationships with a vast number of people in order to perform more efficiently at the workplace. Therefore, the findings of this study would provide insight about emotional management and contribute to the literature.

\section{Two dimensions of workaholism}

Is workaholism an addiction which damages the individual's family and colleagues or is it a rewarding working life and lifestyle? (Liang \& Chu, 2009; Seybold \& Salomone, 1994; Gokalp, 2019). Focusing on this question, some authors aimed to define workaholism, while some conducted research to find out the motives of workaholism. Workaholism is generally defined as the tendency to work excessively and the reluctance to disengage from work (psychological addition to work) (Liang \& Chu, 2009; Lichtenstein et al., 2019). The workaholic individual works so excessively and compulsively that it creates an observable interference with personal health and happiness, and interpersonal relationships (Seybold \& Salomone, 1994).

From an addiction paradigm, many authors define workaholism as an 'addiction' (Liang \& Chu, 2009). Substance dependence means that an addicted individual cannot quit using that substance, although it leads to critical problems. 'Substance dependence' and 'work addiction' can be used interchangeably as substance dependence is a multi-factorial term constituting social, psychological and biological factors (Andreassen et al., 2010; Savarese et al., 2019; Shifron \& Reysen, 2011). Morris and Charney (1983) noted that workaholics suffer from observable symptoms like anxiety and depression which are also among the symptoms of classical addiction (Seybold \& Salomone, 1994). Likewise, Oates (1971) associated alcoholism with workaholism, and remarked that workaholics, like addicts, continue to engage in this lifestyle although they neglect other areas of their lives. These behaviours also negatively influence individual's entire family system and society (Shifron \& Reysen, 2011).

Oates (1971) described the term workaholism as '...the compulsion or the uncontrollable need to work incessantly' (Andreassen et al., 2010). Workaholics feel guilty and disturbed in the absence of work (Schaufeli et al., 2006; Spence \& Robbins, 1992). Such individuals do more than what is expected of them or instructed by the contract (Schaufeli et al., 2006). They devote their time and energy to work (Morkeviciute et al., 2019; Schaufeli et al., 2009) and contemplate about work activities (Schaufeli \& Enzmann, 1998).

Cherrington (1980) regards workaholism as an irrational dependence on excessive working (as cited in Harpaz \& Snir, 2003). Workaholics can also be exposed to the reactions of family members and colleagues (Shifron \& Reysen, 2011). At the same time, workaholics were found to be reluctant and incapable of building intimate relationships with others, indicating the presence of social pessimism. Therefore, workaholics engage in work and can use that as an excuse not to participate in social activities (Morkeviciute et al., 2019). 
In a study by McMillan and O'Driscoll (2006), the workers, their colleagues and partners were asked the question 'How would you describe a workaholic person?' and the two most frequent answers were 'time spent working or thinking about work' (39\%) and 'obsessive personal style' (22\%), presenting $61 \%$ of the total responses. In other words, these two responses correspond, respectively, to the components of WE and working compulsively (WC) (McMillan \& O’Driscoll, 2006; Schaufeli et al., 2006).

Workaholism is a multidimensional construct (Clark et al., 2010). However, depending on a number of studies, Schaufeli et al. (2006) defined workaholism in two dimensions: WE and WC (Spence \& Robbins, 1992).

'WE' represents the behavioural component of workaholism (Morkeviciute et al., 2019). It connotes perceiving work as an obligation, over-commitment to work and obsession with work (Schaufeli et al., 2006). It leads to internal pressure, autonomy, competence and unsatisfying relationships on the part of the workers. WE may be regarded as the tendency to fill the unsatisfied psychological needs through work (Andreassen et al., 2010). It is found via conceptual analyses that workaholics go above and beyond what is reasonably needed due to the internal drivers rather than external ones (Morkeviciute et al., 2019).

On the other side, 'WC' represents the cognitive component of workaholism (Morkeviciute et al., 2019). The most prominent characteristic of workaholics is their work engagement far more than what is needed (Harpaz \& Snir, 2003). Therefore, workaholism requires longer working hours and hard work (Aziz \& Tronzo, 2011). Working hard and compulsively needs to be studied due to the damages to individuals, family systems and the society itself. Workaholism is also described as a safe shelter for individuals who seek an alternative path to escape from emotions and undesired commitments (Dogaheh et al., 2014; Schaufeli et al., 2006). Kucukkaragoz (2020) examined the family environment and emotional part of third-grade students in a primary school.

In today's world, people work more than what is expected of them, and they cannot spare time for their families, social life and hobbies. In other words, excessive and compulsive working brings about many other problems. Due to this fact, the research focus has shifted towards the investigation of the effects of personality variables at workplace. It was also implied in some studies that five personality factors would be handled within workaholism-oriented research in future studies (Burke et al., 2006).

\section{Personality and workaholism}

Workaholism is regarded as a stable variable of individual difference. In a study by Burke et al. (2006), they examined the relationship between workaholism facets and personality factors and they concluded that there was a need to research and identify personality factors (Aziz \& Tronzo, 2011). Ng et al. (2007) proposed a theoretical model, claiming that people are likely to be workaholic as social and cultural experiences and habits may lead to workaholic behaviours (Clark et al., 2010). According to trait theory, basic personality traits have a genetic basis. It may further develop at an early age or it may turn the person into a 'workaholic' in the adulthood period (Andreassen et al., 2010).

Burke et al. (2006) examined the relationship between personality and workaholism by studying the factors and workaholism facets developed by Robbins in 1992 (Aziz \& Tronzo, 2011). The research conducted by Burke et al. (2006), which focused on the relationship between the fivefactor personality model (Costa \& McCrae, 1992) and workaholism, revealed that there was a significant positive association between workaholism and the components of 'neuroticism' and 'EX'. These traits were formerly found to be in positive relationship with job satisfaction (Burke et al., 2006). Kubota et al. (2010) also indicated that nurses, acting in a risk group, encountered some problems like difficulty to wake up, restlessness and sleeping at work. Similarly, Abic and Yilmaz (2019) addressed the problems of the hospital staff and the topics that are psychologically based. Naktiyok and Karabey (2005) introduced consistent results and found that as the level of workaholism increased, the psychological, physical and emotional burnout accelerated (Dogan \& Tel, 2011).

The antecedents of workaholism were also examined in some studies which revealed that variables like demographic characteristics, job characteristics, feeling of incompetence, motivation and drive to empower oneself were correlated to workaholism (Burke et al., 2006). The current explanations emphasise on individual dispositional, sociocultural and reinforcing antecedents, ranging from learning and personality factors to more or less subconscious motives (Liang \& Chu, 2009).

In related research studies, it was found that there was a positive relationship between work enjoyment and work engagement, and 'EX' was correlated to work enjoyment (Burke et al., 2006); 'Agreeableness' was in a relationship with both components of workaholism (Andreassen et al., 2010; as cited in Jackson et al., 2016), and the people who had a low level of neuroticism were found to be comfortable, calm, balanced and compatible (Costa \& McCrae, 1995). On the other side, it was revealed that the dimension of 'emotional instability' accompanied negative feelings like anxiety and depression, and these people tended to be aggressive and pessimistic (Costa \& McCrae, 1995).

There have also been studies which uncovered the positive effects of workaholism (Burke, 2000; Jackson et al., 2016). For example, Machlowitz (1980) conducted a qualitative study by interviewing more than 100 workaholics and showed that they were happy with their way of life. Likewise, Cantarow (1979) communicated that 'joy of creativity' was a facet of workaholic personality (Burke, 2000; Harpaz \& Sinir, 2003).

From a different perspective, Garson (2005) suggested that workaholism can be treated and controlled by practicing 
some behaviours like delegation of authority, recognising the boundaries of job responsibilities and working accordingly and taking lunch breaks (as cited Aziz \& Tronzo, 2011).

\section{The Big Five (BF)}

Personality is the sum of characteristics and traits distinguishing a person from others, gained through education and experiences (Dogan, 2013). McCrae and Costa (1989) defined personality as attitudes, behaviours and interaction style getting constant according to the changing conditions (as cited in Barrick \& Mount, 1991; Cetinkaya \& Keser, 2018). Relevant literature is characterised with many approaches to personality, and it is obvious that trait approach, which emphasises differing behaviour types, has been frequently researched. The five-factor model (FFM) is a conceptual model consisting of five variables or traits which describe personality (Burke et al., 2006). Golberg (1990) alleged that the five basic personality traits can explain individuals' personality characteristics comprehensibly (Burke et al., 2006).

The five-factor personality model which introduced personality traits under five factors are: 1. EX, 2. agreeableness, 3. neuroticism, 4. CO and 5. openness to experience (Barrick \& Mount, 1991; Brouwer et al., 2015; Opayemi \& Balogun, 2011). Most people's personality traits can be categorised into these five, and these five personality dimensions can be generalised to other languages and, therefore, across cultures (Aziz \& Tronzo, 2011).

The dimension of EX implies that such people are sociable, energetic, compassionate, warm, talkative, enthusiastic, outgoing, sympathetic, friendly and cooperative. Additionally, extraverted people are stated to be reward-oriented. The ones whose EX level is low are introvert, inhibited, nonsocial, reserved, hesitant and shy (Dogan, 2013).

Neuroticism is another dimension of personality which places people between emotional stability and constancy of adaptability (Bayram et al., 2019; Erden, 2017). Neuroticism is correlated with instability, stress tendency, lack of selfconfidence and depression (lack of positive psychological adaptability and emotional stability), which increases the possibility of individuals to experience serious physical and psychological symptoms and signs, and become more vulnerable to negative life conditions (Burke et al., 2006). Neurotic individuals suffer from stress more frequently in the face of daily events when compared to others (Bayram et al., 2019). On the contrary, a person who is less neurotic is stated to be more comfortable, calm, stable and adaptive (Costa \& McCrae, 1995).

Agreeableness is utilised to evaluate the quality of interpersonal adaptability in a variety of situations occurring in human emotions, thoughts and behaviours ranging from affection to hostility. Agreeableness paves the way for less interpersonal conflicts and more support for minimising conflicts at workplace and within family systems as adaptive per- sons are more successful and they receive more support from their colleagues and family (Sudak \& Zehir, 2013).

With regard to $\mathrm{CO}$, it comes to mean assertiveness to achieve a goal, perseverance, motivation, patience, organisation and operation. Among all, CO is the most debated factor (Tozkoparan, 2013).

Barrick and Mount (1991) indicated that the benefits of using the five-factor personality model, as it was revealed through research, is that this model is highly effective in testing the psychology of the working staff and their traits; it can be used during staff selection, training, development, performance evaluation and for research and practice.

\section{Emotional intelligence}

EI is a research topic that has achieved too much attention in the psychology literature and in organisational practices (O’Boyle et al., 2010; Petrides et al., 2007;). EI is a personality trait; therefore, what is questioned is where it belongs within established personality hierarchies as opposed to a cognitive ability (Petrides et al., 2007). Salovey and Mayer (1990, p. 189) defined EI in a study they conducted as the 'ability to monitor one's own and others' feelings and emotions, to discriminate among them and to use this information to guide one's thinking and actions'. Mayer and Salovey (1997) proposed that EI includes a number of processes, which are as follows: appraisal and expression of emotion, regulation of emotion and utilisation of emotions (as cited in Charbonneau \& Nicol, 2002).

EI is associated with self-awareness, problem-solving, empathetic approach and prediction of emotions (Mayer \& Salovey, 1997). People who are emotionally intelligent develop self-awareness in the first place and then are aware of other people (Aziz \& Tronzo, 2011). Bar-On (2006) states that $\mathrm{EI}$ is a part of social intelligence and it comprises both emotional and social abilities. Bar-On (2006) also marked that $\mathrm{EI}$ is one of the basic characteristics of effective human behaviours. In other words, emotional-social intelligence requires interrelated emotional and social competencies, skills and facilitators that determine how effectively we understand and express ourselves, understand others and establish and maintain social and interpersonal relationships (Bar-On, 2006).

EI has gained popularity after the publishment of a book on it by Goleman in 1995 (Kun \& Demetrovics, 2010). Goleman (1998) defined EI as 'a capacity to recognise our own emotions' (Khokhar \& Kush, 2009) and Goleman categorised EI into four dimensions (Rahim et al., 2002):

1) Recognition, evaluation and expression of emotions: It is defined as perceiving and defining the emotions of the self (Peter, 2010). In the model proposed by Mayer and Salovey (1997), the level of emotional perception is indicated as low (Mayer \& Salovey, 1997).

2) UoEs: The ability to use emotions (Peter, 2010) connotes using emotions through thinking (Mayer et al., 2004). 
3) Understanding and judging emotions: It is the ability to recognise one's own emotions and others', and to make a comparison between them (Mayer et al., 2004).

4) Management of emotions: It is the ability to be open to emotions of any kind, realise emotions and reduce the negative emotions, while increasing the positive ones, and manage ones' own and others' emotions (Mayer et al., 2004).

Goleman asserts that 'managing one's own emotions' requires the ability of a person to take the control of his/her emotions and reactions, act honestly and consistently and adapt to changes. This ability is also defined as stress management, staying calm and indifferent to others' emotions on the condition of crisis (Erdogdu, 2008; Sudak \& Zehir, 2013;).

Emotion management is one's control of his/her intrinsic state. Individuals manage their emotions in distinct ways and workplaces at which social interactions are established to serve as spaces where emotion management processes could be observed. EI is considered as having a positive effect on the improvement of individual and organisational performance. As Drucker expressed, in today's world, social capital preceded physical resources, and individuals are forced into a tiring and fast state of competition which requires them to gain more knowledge, skills, attitudes and values (Edizler, 2010).

Cesitcioglu (2003) described emotional management as 'a person's keeping his/her brain under the control of rationalism, recognising his/her emotions and identifying strategies to cope with them, neutralising harmful emotions stored subconsciously and living for the moment' Barutcugil (2002) also defined it as 'the ability to distinguish real values from the irrational ones and emotional expectations, and to monitor and guide emotional reflections in a way not to harm individuals' (Akcay \& Coruk, 2012).

Schutte et al. (2007) conducted a meta-analysis to review 35 studies conducted before 2007 in order to find out the relationship between EI and health. Six out of 35 studies fo- cused on the use of proactive substance. The analysis results indicated that alexithymia, frequently discussed in relation to alcohol use, played an important role in emotional regulation and formation of emotional expression, which constitute two dimensions of EI (Kun \& Demetrovics, 2010). The research by Kaveh and Yazdi (2007) additionally revealed that there was a positive relationship between EI and workaholism (Dogaheh et al., 2014).

Effective emotion management is of high importance in individual, organisational and managerial terms to provide a sound operational unity in organisations. Provided that workers overcome emotional problems they encounter at the workplace they get happier and peaceful (Akcay \& Coruk, 2012). The five personality traits reflect the emotional tendencies to be affected by emotional regulation skills. Neuroticism is associated with openness to experience both positive and negative emotions, and it proves the need for adaptiveness, CO, interpersonal and work-based emotional regulation, respectively (Balgiu, 2020; Lopes, Salovey \& Straus, 2003). This situation demonstrates the relationship between the five personality factors and various dimensions of EI. Siegling et al. (2014) also provided evidence through a meta-analysis which aimed to investigate the relationship between EX and emotional stability, and revealed that there was a significant relationship between the BF and EI (Ansari \& Talan, 2017).

There have been some studies which investigated the relationship between workaholism and personality factors; however, the mediating role of UoE in this relationship has been underresearched so far. Therefore, in order to fill in the gap, this study aimed to examine the relationship between the dimensions of workaholism and the factors of EX and CO. In order words, this research sought answers to the following research questions: 1) Is there a significant relationship between the components of workaholism (WE and WC) and the factors of EX and CO? and 2) Does the UoEs play a mediating role in this relationship? In this context, hypotheses were formulated as are in the following figure (Figure 1).

Figure 1

Research model.

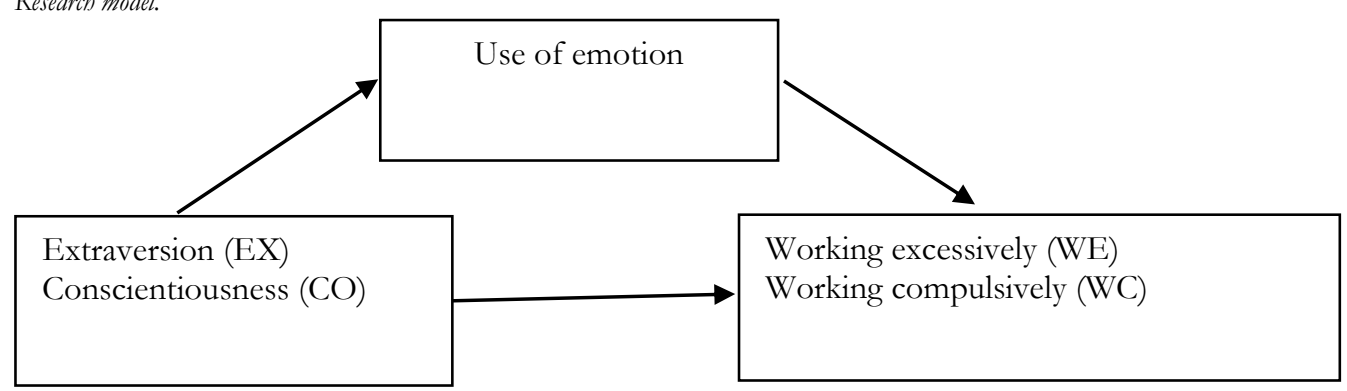

H1: UoE acts as a mediator in the relationship between EX and WE.

H2: UoE acts as a mediator in the relationship between CO and WE.

H3: UoE acts as a mediator in the relationship between EX and WC.

H4: UoE acts as a mediator in the relationship between $C O$ and WC. 


\section{Purpose of the study}

The purpose of this study was to investigate the mediating role of UoE in the relationship between workaholism and personality traits. More specifically, this study aimed to examine the relationship between $\mathrm{EX}$ and $\mathrm{CO}$ components of BF personality factors, subscales of WE and WC in Dutch work addiction scale (DUWAS), and UoE dimension of the emotional intelligence (EI) Scale.

\section{Method}

The general survey model was used in the research. It is a quantitative research. The general screening model is the screening arrangements made on the whole universe or a group of samples or samples to be taken from it in order to reach a general judgment about the universe in a universe consisting of many elements (Gurbuz \& Sahin, 2018; Karasar, 2005).

\section{Data collection procedures}

In this study, data were collected via a questionnaire administered to doctors, nurses and other healthcare staff working at sampled private hospitals in İstanbul. Data were collected from 340 healthcare staff via questionnaire between March and April 2019. However, 15 questionnaires were excluded from the study as they were not filled completely. Therefore, the total number of completed questionnaires was 325 .

Questionnaires were completed on voluntary basis. Healthcare staff working at private hospitals in Istanbul participated in the study upon their consent. These participants were selected through convenience sampling strategy. Convenience sampling strategy is a non-probability sampling strategy used by the researcher to select a sample out of the population.

\section{Participants}

Out of the 340 questionnaires administered between March 2019 and April 2019, 325 questionnaires were found to be complete. As displayed in Table 1, demographic findings indicated that $78.2 \%(n=254)$ of the participants were female, while $21.8 \%$ of them $(n=71)$ were male. Most of the participants, totally 258 of them, were either aged below 25 $(55.1 \%)$ or between 25 and 29 years $(24.3 \%)$. The participants aged between 30 and 34 years constituted $11.1 \%$, while the healthcare staff aged 35 years or above were totally 31 , representing $9.5 \%$ of the participants.

Concerning the educational background, it was found that nearly half of the participants, $58.8 \%$ of them, held bachelor's degree. On the other hand, 116 participants $(35.7 \%)$ reported that they graduated from high school, while a very few of them, only $4 \%$, completed postgraduate studies. Among all, only five participants were found to have graduated from primary/elementary school.

The participants were also asked to report their job status. As revealed by the findings, $59.7 \%$ of the participants $(n$ $=194$ ) were either doctors or nurses, $24.9 \%$ of them worked in administrative positions and 50 participants $(15.4 \%)$ were labelled as 'other staff' (see Table 1).

Table 1

Demographic characteristics of participants

\begin{tabular}{llll}
\hline & & $n$ & $\%$ \\
\hline Gender & Male & 71 & 21.8 \\
& Female & 254 & 78.2 \\
& $\leq 25$ & 179 & 55.1 \\
Age & $25-29$ & 79 & 24.3 \\
& $30-34$ & 36 & 11.1 \\
& $\geq 35$ & 31 & 9.5 \\
Educational background & 5 & 1.5 \\
& Primary/elementary School & 116 & 35.7 \\
& High School & 191 & 58.8 \\
& Undergraduate & 13 & 4.0 \\
Experience & Post-graduate & 104 & 32.0 \\
& $<1$ year & 112 & 34.5 \\
& 1-5 years & 57 & 17.5 \\
Job status & 6-10 years & 52 & 16.0 \\
& $\geq 11$ years & 81 & 24.9 \\
& Administrator & 194 & 59.7 \\
& Doctor/nurse & 50 & 15.4 \\
\hline
\end{tabular}

\section{Measures}

The DUWAS was developed by Schaufeli et al. (2006) in order to measure workaholism. The scale consists of 17 items. In the original version, a 4-point Likert-type scale ranging from 1 (never) to 4 (always) was used. The scale was adapted to Turkish and the validity and reliability measurements of the scale were conducted by Dogan and Tel (2011). The adapted version utilised a 5-point Likert scale (ranging from 1: never fits to 5: totally fits) in order to make it more comprehensible in Turkish. It is a self-report scale including five options for scoring.

Additionally, expressions pertaining to the agreeableness dimension of the personality types scale developed by De Raad, Sullot and Barelds (2008) were included in the questionnaire designed to collect data in this study.

Besides, the self-emotions appraisal (SEA) dimension of the EI Scale developed by Law, Wong and Song (2004) was utilised in the research questionnaire. This scale is a selfreport with 16 items categorised into four dimensions, each of which includes four items.

\section{Results}

\section{Descriptive statistics}

The data collected via the questionnaire were analysed through SPSS 22.0 and AMOS 22.0 and interpreted. Con- 
firmatory factor analyses of the scales utilised in this study were conducted through AMOS, and Cronbach's alpha, AVE and CR values were calculated. Mediating effects of the variables were analysed through the structural equation modelling on AMOS using the bootstrapping method.

\section{Confirmatory factor analysis (CFA)}

CFA was run in order to confirm the significance of factor models within each scale through AMOS 22.0. When the findings were examined, the factors were found to be acceptable. Following that, the whole model was tested through fit indices (see Table 2).

As the sample size increases, especially the samples larger than 200 , the value of chi-square $\left(\chi^{2}\right)$ increases and the statistical significance of this test tends to decrease (Bagozzi et al., 1999; Bollen, 1989; Fornell \& Larcker, 1981). Therefore, in this study, chi-square $\left(\chi^{2}\right)$ values corrected through degrees of freedom (chi-square value/degrees of freedom), goodness-of-fit indices and values featured in standardised residual covariance matrices were utilised in order to interpret the results of confirmatory factor analysis and fit indices of the hypothesised models (Bayram, 2013).

Table 2

Goodness-of-fit indices and fit values used in CFA.

\begin{tabular}{lll}
\hline Indexes & Good fit & General rule for acceptable fit \\
\hline$\chi^{2} / \mathrm{df}$ & $0 \leq \chi^{2} / \mathrm{df} \leq 2$ & $2<\chi^{2} / \mathrm{df} \leq 3$ \\
GFI & $\geq 0.90$ & $0.85-0.89$ \\
CFI & $\geq 0.97$ &,$\geq 0.95$ \\
SRMR & $\leq 0.05$ & $0.06 \leq$ SRMR $\leq 0.08$ \\
RMSEA & $\leq 0.05$ & $0.06 \leq$ RMSEA $\leq 0.08$ \\
\hline
\end{tabular}

The four-item EX dimension of the 16-item BF Scale and two items from the $\mathrm{CO}$ dimension were removed from the analysis due to the factor loadings below 0.50. Likewise, six items were removed from the DUWAS due to low factor loadings. On the other hand, four items pertaining to the UoE component of the EI Scale were completely retained. Factor loadings ranged from 0.62 to 0.99 in the model (see Table 3).

Table 3

CFA of the model.

\begin{tabular}{|c|c|c|c|c|c|c|}
\hline & & & Estimate & Standard Estimate & C.R. & $p$ \\
\hline Extraversion1 & $<---$ & EX & 1.000 & 0.990 & & \\
\hline Extraversion 2 & $<--$ & $\mathrm{EX}$ & 0.872 & 0.946 & 23.846 & $* * *$ \\
\hline Conscientiousness 12 & $<---$ & $\mathrm{CO}$ & 0.978 & 0.812 & 16.808 & $* * *$ \\
\hline Conscientiousness 11 & $<--$ & $\mathrm{CO}$ & 1.000 & 0.933 & & \\
\hline Working Excessively 4 & $<---$ & WE & 1.000 & 0.888 & & \\
\hline Working Excessively 8 & $<--$ & WE & 1.010 & 0.639 & 8.928 & $* * *$ \\
\hline Working Excessively 10 & $<---$ & WE & 1.093 & 0.836 & 17.894 & $* * *$ \\
\hline Working Excessively 12 & $<--$ & WE & 0.794 & 0.707 & 10.345 & $* * *$ \\
\hline Working Excessively 13 & $<---$ & WE & 1.060 & 0.664 & 9.171 & $* * *$ \\
\hline Working Excessively 15 & $<---$ & WE & 0.798 & 0.776 & 13.12 & $* * *$ \\
\hline Working Excessively 17 & $<---$ & WE & 1,225 & 0.654 & 8.747 & $* * *$ \\
\hline Working Compulsively 7 & $<---$ & WC & 1.000 & 0.837 & & \\
\hline Working Compulsively 11 & $<---$ & WC & 1.280 & 0.754 & 11.037 & $* * *$ \\
\hline Working Compulsively 14 & $<---$ & WC & 1.108 & 0.623 & 9.458 & $* * *$ \\
\hline Working Compulsively 16 & $<---$ & WC & 1.386 & 0.656 & 9.870 & $* * *$ \\
\hline Use of Emotion 9 & $<---$ & $\mathrm{UOE}$ & 0.979 & 0.756 & 12.233 & $* * *$ \\
\hline Use of Emotion 10 & $<---$ & UOE & 0.984 & 0.721 & 11.737 & $* * *$ \\
\hline Use of Emotion 11 & $<---$ & UOE & 1.121 & 0.674 & 10.989 & $* * *$ \\
\hline Use of Emotion 12 & $<--$ & UOE & 1.000 & 0.784 & & \\
\hline
\end{tabular}

${ }^{* * *} p<.001 ;{ }^{* *} p<.01 ;{ }^{*} p<.05$.

Model test values $\left(p<0.05, \chi^{2}=452.568, \chi^{2} / \mathrm{df}=3.187\right)$ revealed through confirmatory factor analysis confirmed the significance of measurement portion of the model. Fit indices of the overall model [GFI (0.911), CFI (0.949), SRMR (0.0707), RMSEA (0.0767)] were between the acceptable levels confirming the validity of the model fit (Gurbuz \& Sahin, 2014).

\section{Validity and reliability}

The validity and reliability of a scale indicate that the scores remain the same when the instrument is administered to the same sample at different times. In order to test the reliability of the scale utilised in this study, Cronbach's alpha, which is an internal consistency value indicating the correlation among items, was calculated. It indicates the total reliability score of items given under factors. Reliability coefficient scores of 0.70 and above indicate that the scale is relia- 
ble. However, in case of a lower number of items, the value of 0.60 and above can be accepted (Raykov, 1997).

Combined reliability (CR) values are calculated through factor loadings. It can be said that combined reliability is established in case the CR values are 0.70 and above.

The value for convergent reliability is indicated with the average variance extracted (AVE). For convergent reliability, the AVE value must be 0.50 and above (Fornell \& Larcker, 1981). With regard to divergent reliability, square root dimensions of AVE values must be higher than the correlation with other dimensions; thus, the divergence among each dimension within a scale can be established (Fornell \& Larcker, 1981).

Table 4

Correlations, reliability and divergent reliability values of the scales.

\begin{tabular}{|c|c|c|c|c|c|c|c|}
\hline Sub-dimensions & $\mathrm{M}$ & $\mathrm{SD}$ & WE & WC & EX & $\mathrm{CO}$ & UOE \\
\hline $\mathrm{WE}$ & 3.52 & 0.91 & $(0.738)$ & & & & \\
\hline WC & 3.41 & 1.12 & $0.704^{* *}$ & $(0.709)$ & & & \\
\hline EX & 3.34 & 0.92 & $0.385^{* *}$ & $0.420^{* *}$ & $(0.968)$ & & \\
\hline $\mathrm{CO}$ & 3.91 & 0.91 & $0.225^{* *}$ & $0.200^{* *}$ & $0.235^{* *}$ & $(0.874)$ & \\
\hline UoE & 4.3 & 0.85 & $0.235^{* *}$ & $0.154^{* *}$ & $0.307^{* *}$ & $0.293^{* *}$ & $(0.734)$ \\
\hline Reliability coefficient Cronbach's Alpha & - & - & 0.812 & 0.801 & 0.897 & 0.854 & 0.808 \\
\hline$C R$ & - & - & 0.892 & 0.883 & 0.968 & 0.866 & 0.824 \\
\hline Average variance Extracted (AVE) & - & - & 0.546 & 0.503 & 0.938 & 0.765 & 0.540 \\
\hline
\end{tabular}

***p $<.001 ;{ }^{* *} p<.01 ;{ }^{*} p<.05$.

WE: working excessively, WC: working compulsively, EX: extraversion, CO: conscientiousness UoE: use of emotion.

As shown in Table 4, the reliability analyses showed that the reliability coefficients were above 0.80 for WE and WC dimensions of DUWAS, EX and CO facets of the BF Scale, and UoE component of the EI Scale, indicating all the factors had good level of internal consistency. With regard to the combined reliability, all CR values were found be above 0.70 , indicating that the assumption of combined reliability was met. Additionally, the AVE value was calculated for all variables to ensure convergent reliability, and variance values were found to be above 0.50 ; therefore, convergent reliability of the items was established. Finally, divergent reliability was checked and the square roots of the AVE values are given in parentheses in Table 4. As these values are higher than the correlations given in that column, it was accepted that divergent reliability was established for all variables.

\section{Assumptions of structural equation modelling (SEM)}

The major assumptions associated with structural equation modelling generally are a) multivariate normality, b) linearity, c) sample size and d) scale type. Multivariate normality is a critical assumption in SEM. In case this assumption is not met, large differences can be achieved in the chi-square test and insignificant findings can be interpreted as signifi- cant. On the condition that this assumption is violated, then weighted methods independent from the distribution are recommended (Raykow \& Marcoulides, 2006).

It is also assumed in structural equation modelling that there is a linear relationship between endogenous and exogenous variables. As another assumption of SEM, data must be collected with interval scales. In order to meet the assumption of normal distribution, Skewness and Kurtosis values are checked and the scores must be ranging between \pm 1.5 for normal distribution (Dogan \& Basokcu, 2010, pp. 65-66). Due to that, maximum likelihood method was employed.

\section{Testing the mediator variable effect in AMOS}

Before testing the model, means, medians and standard deviations were tabulated for all variables in SPSS 22.0. The model, shown in Figure 2, was tested in AMOS 22.0 by running path analysis with the observed variables (Kline, 2005). As the indirect effects were found to be insignificant and since the assumption of normal distribution was not fully met, the bootstrapping method was utilised rather than the Sobel test by resampling with replacement of at least 2000 times at the confidence interval of $95 \%$. 
Figure 2

Mediator path analysis model tested in the research.

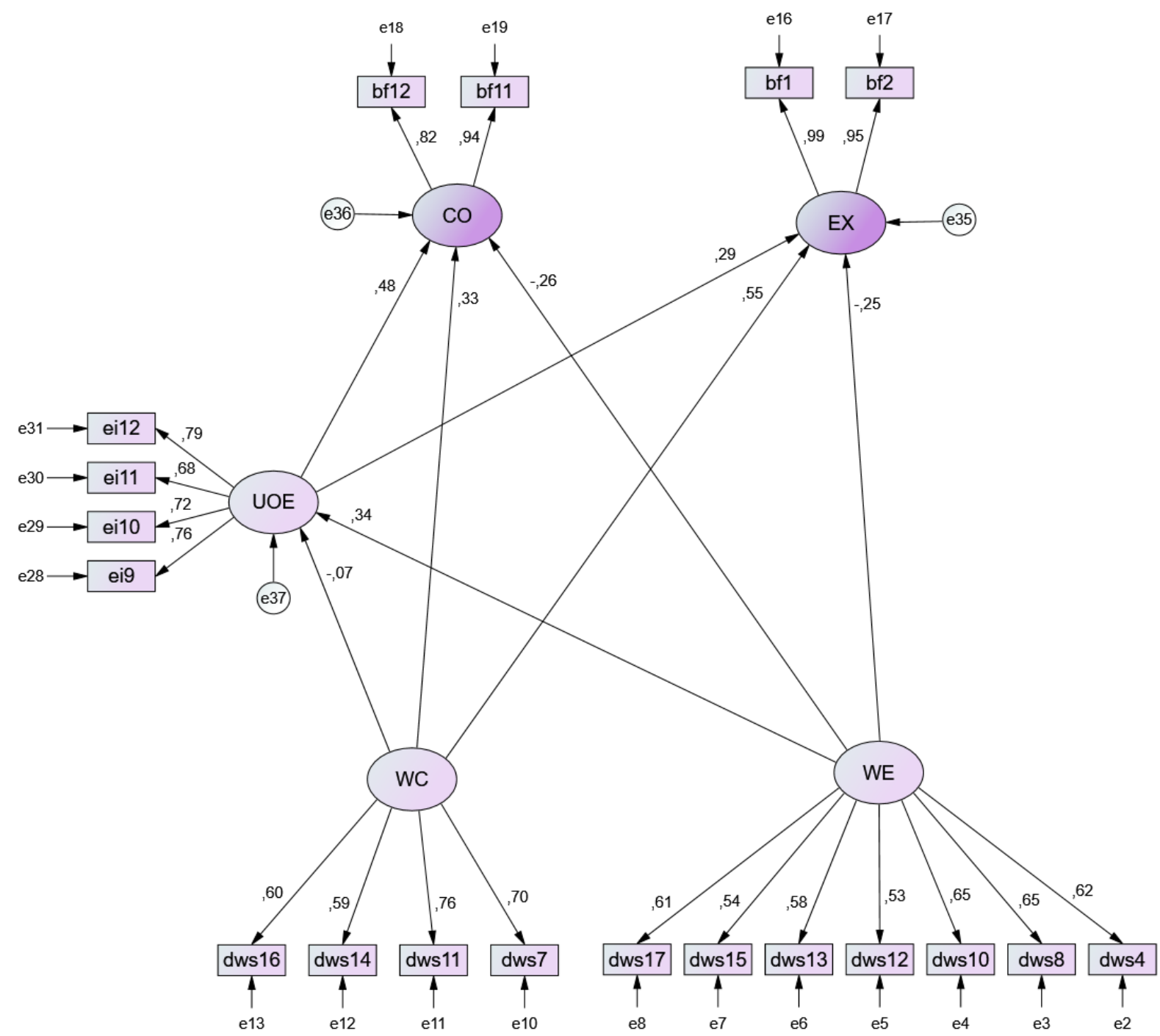

The model was found to be significant as indicated through latent variable path analysis $\left[\chi^{2}\right.$ (717.12), $\chi^{2} / \mathrm{df}$ (4.98) and $(p<0.05)]$. Fit indices of the model were GFI (0.865), CFI (0.924), SRMR (0.0788) and RMSEA (0.080), and the model was validated as the values are within the ac-

Table 5

Direct and indirect relationships between independent, dependent and mediator variables.

\begin{tabular}{|c|c|c|c|c|c|}
\hline Hypothesis & Direct effect & Direct effect $p$ & Indirect effect & Indirect effect $p$ & Result \\
\hline $\mathrm{WE} \rightarrow \mathrm{UoE} \rightarrow \mathrm{EX}$ & -0.358 & 0.167 & 0.147 & $0.019^{*}$ & Full mediation \\
\hline $\mathrm{WE} \rightarrow \mathrm{UoE} \rightarrow \mathrm{CO}$ & -0.295 & 0.118 & 0.184 & $0.020^{*}$ & Full mediation \\
\hline $\mathrm{WC} \rightarrow \mathrm{UoE} \rightarrow \mathrm{EX}$ & 0.811 & $0.003^{* *}$ & -0.029 & 0.626 & No mediation \\
\hline $\mathrm{WC} \rightarrow \mathrm{UoE} \rightarrow \mathrm{CO}$ & 0.376 & 0.078 & -0.037 & 0.617 & No mediation \\
\hline
\end{tabular}

${ }^{*} p<.05 ;{ }^{* *} p<.01$.

WE: working excessively, WC: working compulsively, EX: extraversion, CO: conscientiousness, UoE: use of emotion.

In this study, which was conducted with the participation of 325 healthcare staff, the mediator role of UoE in the ef- ceptable levels. Insignificant path values $(p>0.05)$ were observed to moderate model fit indices. Direct and indirect relationships tested by bootstrapping $(n=2,000)$ are given in Table 5. fect of WE on the variables of EX and CO, and the mediator role of $\mathrm{UoE}$ in the effect of WC on the variables of $\mathrm{EX}$ 
and $\mathrm{CO}$ are examined in detail. The findings obtained through the bootstrapping $(n=2,000)$ method are as follows:

- In the model, the direct effect of WE on EX was not significant $(\beta=-0.358 ; p>0.05)$; however, there was a significant indirect effect of WE on EX through UoE $(\beta$ $=0.147 ; p<0.05)$. Because of this, it was seen that $\mathrm{UoE}$ acted as a full mediator in the effect of WE on EX, indicating a positive relationship between WE and EX through UoE.

- Similarly, the direct effect of WE on CO was found to be insignificant $(\beta=-0.295 ; p>0.05)$, while indirect effect of WE on CO through $\operatorname{UoE}(\beta=0.184 ; p<0.05)$ was significant, which revealed that the $\mathrm{UoE}$ acted as a full mediator in the effect of WE on CO.

- The direct effect of WC on EX was found significant in the model $(\beta=0.811$; $p<0.05)$; on the other hand, indirect effect of WC on EX through the UoE was not significant $(\beta=-0.029 ; p>0.05)$. Therefore, the UoE did not act as a mediator in the relationship between working compulsively (WC) and EX.

- Finally, both the direct effect of working compulsively (WC) on $\mathrm{CO}(\beta=0.376 ; p>0.05)$ and the indirect effect of working compulsively (WC) on $\mathrm{CO}$ through the $\mathrm{UoE}$ $(\beta=-0.037 ; p>0.05)$ were not found statistically significant. Therefore, the UoE variable did not play a mediator role in the effect of $\mathrm{WC}$ variable on $\mathrm{CO}$ variable.

\section{Discussion and conclusion}

Together with the instable conditions in the world, it is believed that there has been an increase in the excessive and compulsive way of working. This study examined the mediator role of the UoE component of the EI Scale in the relationship between EX and $\mathrm{CO}$ within the BF personality factors, and the dimensions of WE and WC of the DUWAS.

In this study, the relationship between two dimensions of workaholism, which are WE and WC, and personality fac-

\section{References}

Abic, A. \& Yilmaz, D. (2019). Infertility risk factors and nurse's role. International Journal of Emerging Trends in Health Sciences, 3(1), 1-8. https://doi.org/10.18844/ijeths.v3i1.4073

Akcay, C. \& Coruk, A. (2012). Calisma yasaminda duygular ve yonetimi: Kavramsal bir inceleme [Emotions and their management in working life: A conceptual review]. Egitimde Politika Analizi Dergisi, 1(1), 3-25.

Andreassen, C. S., Hetland, J. \& Pallesen, S. (2010). The relationship between 'workaholism', basic needs satisfaction at work and personality. European Journal of Personality, 24(1), 3-17. https://doi.org/10.1002/per.737

Ansari, A. H. \& Talan, A. (2017). Emotional intelligence and work engagement as mediators of big five personality and knowledge sharing. Global Journal of Enterprise Information System, 9(3), 16-26. https://doi.org/10.18311/gjeis/2017/16357

Aziz, S. \& Tronzo, C. L. (2011). Exploring the relationship between workaholism facets and personality traits: a replication in American workers. The Psychological Record, 61(2), 269-286. tors of EX and CO and mutual effects, and finally the role of UoE as a mediator in these relationships were examined. The UoE fully mediates the relationship between, WE and $\mathrm{CO}$. On the contrary, the UoE was not found as a mediator in the effect of compulsive work (WC) on EX and CO.

The findings obtained in this study reveal consistencies with the findings of some other studies in the literature. As mentioned earlier, a significant relationship was not found between WE, WC and CO. Consistently, some studies did find out significant relationship between $\mathrm{CO}$ and workaholism (Andreassen \& digerleri 2010; Aziz \& Tronzo, 2011; Schaufeli \& Digerleri, 2008). In fact, the individuals who are conscientious are found to be sociable and extraverted (Doğan 2013).

The findings of this research also did not reveal a direct positive relationship among the dimensions of workaholism. Nevertheless, the UoE was found to have an impact in the relationship between WE, WC and CO. When UoE is controlled, there occurs a positive relationship between WE and CO. It can be said that the UoEs through thinking can lead to the control and management of emotions. The UoE had a positive effect on the relationship between WE, CO and EX.

Further studies should be conducted with the participation of the same occupational group from distinct countries in order to identify the personality differences among these and to reveal the differences between WE and WC more apparently.

The relationship between jobs, leadership styles, work characteristics, personality traits and workaholism should be examined in future studies. Conducting studies which examine the positive effects of workaholism can also attract the attention of management bodies.

As a limitation of this study, the relationship between workaholism and personality traits were not examined in terms of job status of the healthcare providers. Further comparative studies should be conducted to reveal the differences among people with different job status in terms of workaholism and personality traits.

Bagozzi RP, Gopinath M, Nyer PU. The Role of Emotions in Marketing. Journal of the Academy of Marketing Science. 1999;27(2):184-206. https://doi.org/10.1177/0092070399272005

Bagozzi, R. \& Yi, Y. (2012). Specification, evaluation and interpretation of structural equation models. Journal of the Academy of Marketing Science, 40(1), 8-34.

Balgiu, B. (2020). Curiosity and subjective well-being: The mediation of the big five personality traits. Global Journal of Psychology Research: New Trends and Issues, 10(1), 151-159. https://doi.org/10.18844/gipr.v10i1.4458

Bar-On, R. (2006). The Bar-on model of emotional-social intelligence. Psicothema, 18, 13-25.

Barrick, M. R. \& Mount, M. K. (1991). The big five personality dimensions and job performance: a meta-analysis. Personnel Psychology, 44(1), 1-26. https://doi.org/10.1111/j.1744-6570.1991.tb00688.x

Bayram, A., Demirtas, O. \& Karaca, M. (2019). Bes faktor kisilik ozelliklerinin insan enerjisi uzerindeki etkisi: Bir alan arastirmasi [The effect of perosnality traits on human energy: a Field Study]. Anadolu Akademi 
Sosyal Bilimler Dergisi, 1(1), 4-22. Retrieved from http://dergipark.org.tr/anadoluakademi/issue/42510/505586

Bayram, N. (2013). Yapisal esitlik modellemesine giris amos uygulamalari [Introduction to Structural Equation Modeling: AMOS Applications]. Balıkesir, Turkey: Ezgi Yayinevi.

Bollen, K. A. (1989). Structural equations with latent variables. Hoboken, NJ: Wiley.

Brouwer, A-M., van Schaik, M. G., Korteling, J. E. H., van Erp, J. B. F. \& Toet, A. (2015). Neuroticism, extraversion, conscientiousness and stress: physiological correlates. IEEE Transactions on Affective Computing, 6(2), 109-117. https://doi.org/10.1109/TAFFC.2014.2326402

Burke, R. J. (2000). Workaholism in organizations: concepts, results and future directions. International Journal of Management Reviews, 2, 1-16.

Burke, R. J., Matthiesen, S. B. \& Pallesen, S. (2006). Personality correlates of workaholism. Personality and Individual Differences, 40(6), 1223-1233. https://doi.org/10.1016/i.paid.2005.10.017

Caruso, D. R. \& Salovey, P. (2004). The emotionally intelligent manager: how to develop and use the four key emotional skills of leadership. CA: Jossey-Bass A Wiley Imprint.

Çeşitcioğlu, M. (2003). Kaliteli insan. Alfa Yayinevi, Turkey

Cetinkaya, L. \& Keser, H. (2018). Adaptation of interaction in web environments with educational content. World Journal on Educational Technology: Current Issues, 10(3), 142-152. https://unpub.eu/ojs/index.php/wjet/article/view/3555

Charbonneau, D. \& Nicol, A. A. M. (2002). Emotional intelligence and leadership in adolescents. Personality and Individual Differences, 33, 11011113.

Clark, M, A., Michel, J, S., Zhdanova, L., Pui, S. Y. and Baltes, B. B. (2006). All Work and No Play? A Meta-Analytic Examination of the Correlates and Outcomes of Workaholism. Journal of Management, 42(7), 1836-1873. https://doi.org/10.1177/0149206314522301

Clark, M. A., Lelchook, A. M. \& Taylor, M. L. (2010). Beyond the big five: How narcissism, perfectionism, and dispositional affect relate to workaholism. Personality and Individual Differences, 48(7), 786-791. https://doi.org/10.1016/i.paid.2010.01.013

Costa, P.T. \& Mccrae, R.R. (1995). Domains and facets: Hierarchical personality assessment using the revised neo personality inventory. Journal of Personality Assessment, 64(1), 21-50.

De Raad, B., Sullot, E. \& Barelds, D. P. H. (2008). Which of the Big Five factors are in need of situational specification? European Journal of Personality, 22(4), 269-289. https://doi.org/10.1002/per.668

Degirmenci, F., Yilmaz, D. \& Uzel, A. (2019). Evidence based care for couples with fertility problems. International Journal of Emerging Trends in Health Sciences, 3(1), 22-28. https://doi.org/10.18844/ijeths.v3i1.4095

Dogaheh, E. R., Khaledian, M. \& Arya, A.R.M. (2014). The relationship of psychological hardiness with emotional intelligence and workaholism. Iranian Journal of Clinical Psychology (IJCP), 2(1). http://ipcp.uswr.ac.ir

Dogan, N. \& Basokcu, T. O. (2010). Istatistik tutum olcegi icin uygulanan faktor analizi ve asamali kumeleme analizi sonuclarinin karsilastırilmasi [Comparison of findings of stratified cluster analysis with factor analysis of statistical attitude scale]. Egitimde ve Psikolojide Olcme ve Degerlendirme Dergisi, 1(2), 65-71.

Dogan, T. \& Tel, F. I. (2011). Duwas iskoliklik olcegi Turkce formunun (Duwastr) gecerlik ve guvenirliginin incelenmesi [Validity and reliability study of Turkish version of Duwas workaholism scale (Duwastr]. AIBU Egitim Fakultesi Dergisi, 11(1), 61-69.

Dogan, T. (2013). Bes faktor kisilik ozellikleri ile oznel iyi olus [Personal well-being with five factor personality traits]. Dogus Universitesi Dergisi, 14(1), 56-64.

Edizler, G. (2010). Insan kaynakları yonetiminde duygusal Zeka Olcum Modelleri [Measurement of emotional intelligence in human resourcs management]. Journal of Yasar University. 5(18): 2970-2984

Erden, S. (2017). Enhancing hope, resilience, emotional and interpersonal skills in counsellor trainees: a controlled trial. New Trends and Issues Proceedings on Humanities and Social Sciences, 4(6), 51-59. https://doi.org/10.18844/prosoc.v4i6.2912

Erdogdu, M. Y. (2008). Duygusal Zeka'nın Bazı Degiskenler Acisından Incelenmesi [An Analysis of Emotional Intelligence in Terms of Some Variables]. Elektronik Sosyal Bilimler Dergisi, 7(23), 62-76.
Fornell, C. \&Larcker, D. (1981). Evaluating structural equation models with unobservable variables and measurement error. Journal of Marketing Research, 39-50.

Garson, B. (2005). Work addiction in the age of information technology: an analysis. IIMB Management Review. https://repository.iimb.ac.in/handle/2074/12456

Gedizler, G. (2010). Insan kaynaklari yonetiminde 'duygusal zeka'olcum ve modelleri ["Emotional intelligence" measurement and models in human resources management]. Journal of Yasar University, 5(18), 2970-2984.

Gokalp, M. (2019). Analysis of communication styles between adolescents and parents (example of Kyrgyzstan). Contemporary Educational Researches Journal, 9(4), 119-127. https://doi.org/10.18844/ceri.v9i4.4442

Golberg M.A. (1990) Introduction to the Numerical Solution of Cauchy Singular Integral Equations. In: Golberg M.A. (eds) Numerical Solution of Integral Equations. Mathematical Concepts and Methods in Science and Engineering, vol 42. Springer, Boston, MA. https://doi.org/10.1007/978-14899-2593-0_5

Goleman, D. (1995) Emotional intelligence. Bantam Books, Inc New York, NY

Griffiths, M. (2005). Workaholism is still a useful construct, Addiction Research and Theory, 13(2), 97-100.

Gurbuz, S. \& Sahin, F. (2018). Sosyal bilimlerde arastrma yontemleri [Research methods in social sciences]. Ankara, Turkey: Seckin Yayincilik.

Harpaz, I. \& Snir, R. (2003). Workaholism: its definition and nature. Human Relations, 56(3), 291-319.

Jackson, S. S., Fung, M.-C., Moore, M.-A. C. \& Jackson, C. J. (2016). Personality and workaholism. Personality and Individual Differences, 95, 114 120. https://doi.org/10.1016/j.paid.2016.02.020

Karasar, N. (2005). Bilimsel arastrma yontemi [Scientific research method]. Ankara, Turkey: Nobel Yayinevi.

Kaveh, K., \& Yazdi, S. M. (2007). The relationship between emotional intelligence and psychological hardiness comparison of male and female students working in universities in Tehran. Journal of Innovative Education. $3(1,2): 35-50$

Khokhar, C. P. \& Kush, T. (2009). Emotional intelligence and work performance among executives. Europe's Journal of Psychology, 1-11. https://doi.org/10.5964/ejop.v5i1.281

Kline, R. B. (2005). Principles and practice of structural equation modelling. New York, NY: The Guilford Press.

Kubota, K., Shimazu, A., Kawakami, N., Takahashi, M., Nakata, A. and Schaufeli, W. B. (2010). Association between Workaholism and Sleep Problems among Hospital Nurses. Industrial Health, 48(6) p.864. https://doi.org/10.2486/indhealth.MS1139

Kucukkaragoz, H. (2020). Family environment and emotional quotient in primary school 3rd grade students. Cypriot Journal of Educational Sciences, 15(2), 336-348. https://doi.org/10.18844/cjes.v15i2.4805

Kun, B. \& Demetrovics, Z. (2010). Emotional intelligence and addictions: a systematic review. Substance use esmisuse, 45(7-8), 1131-1160. https://doi.org/10.3109/10826080903567855

Law, K. S., Wong, C. S. \& Song, L. J. (2004). The construct validity of emotional intelligence and its potential utility for management studies. Journal of Applied Psychology, 89(3), 483-496.

Liang, Y. -W. \& Chu, C. -M. (2009). Personality traits and personal and organizational inducements: antecedents of workaholism. Social Behavior and Personality: An International Journal, 37(5), 645-660. https://doi.org/2224/sbp.2009.37.5.645

Lichtenstein, M. B., Malkenes, M., Sibbersen, C. \& Hinze, C. J. (2019). Work addiction is associated with increased stress and reduced quality of life: Validation of the Bergen Work Addiction Scale in Danish. Scandinavian Journal of Psychology. https://doi.org/10.1111/sjop.12506

Lopes, P. N., Salovey, P. \& Straus, R. (2003). Emotional intelligence, personality, and the perceived quality of social relationships. Personality and Individual Differences, 35(3), 641-658. https://doi.org/10.1016/s0191$8869(02) 00242-8$

Machlowitz, M. (1980). Workaholics, living with them, working with them. Addison Wesley Publishing, St, San Francisco, California, United States.

Mayer, J. D. \& Salovey, P. (1993). The intelligence of emotional intelligence. Intelligence, 17(4), 433-442. https://doi.org/10.1016/01602896(93)90010-3 
Mayer, J. D., Salovey, P. \& Caruso, D. R. (2004). Target artıcles: "emotional intelligence: theory, findings, and implications". Psychological Inquiry, 15(3), 197-215.

McMillan, L. H. W. \& O’Driscoll, M. P. (2006). Exploring new frontiers to generate an integrated definition of workaholism. In R. J. Burke (Ed.), Research companion to working time and work addiction (pp. 89-107). Northhampton, MA: Elgar.

Morkeviciute, M., Endriulaitiene, A. \& Jočciene, E. (2019). Do dimensions of transformational leadership have an effect on workaholism? Baltic Journal of Management. https://doi.org/10.1108/bim-06-2018-0240

Morris, S. and Charney, N. 1983. Breaking the Caffeine Habit. Psychology Today, 9: 84.

Naktīyok, A., Karabey, C. (2010). İșkoliklik ve tükenmișlik sendromu. Atatürk. Üniversitesi İktisadi ve İdari Bilimler Dergisi, 19(2), 179-198. Retrieved from https://dergipark.org.tr/en/pub/atauniiibd/issue/2688/35327

O’Boyle, E. H., Humphrey, R. H., Pollack, J. M., Hawver, T. H. \& Story, P. A. (2010). The relation between emotional intelligence and job performance: a meta-analysis. Journal of Organizational Behavior, 32(5), 788-818. https://doi.org/10.1002/job.714

Opayemi1, A.S and Balogun, S.K. (2011). An International Journal - Extraversion, conscientiousness, goal management and lecturing profession in Nigeria. IFE PsychologIA: An International Journal. 19(2), 65-74. https://journals.co.za/content/ifepsyc/19/2/EJC38892

Ozdemir Beceren, B. \& Adak Ozdemir, A. (2020). Description of psychosocial traits of preschool education teachers and investigation of correlations between these traits. Cypriot Journal of Educational Sciences, 15(2), 153-170. https://doi.org/10.18844/cjes.v15i2.4290

Peter, P. C. (2010). Emotional intelligence. Wiley International Encyclopedia of Marketing.USA

Petrides, K. V., Pita, R. \& Kokkinaki, F. (2007). The location of trait emotional intelligence in personality factor space. British Journal of Psychology, 98, 273-289. https://doi.org/10.1348/000712606X120618

Rahim, M. A., Psenicka, C., Polychroniou, P. \& Zhao, J. H. (2002). A model of emotional intelligence and conflict management strategies: a study in seven countries. International Journal of Organizational Analysis, 10(4).

Raykov, T. (1997). Estimation of composite reliability for congeneric measures. Applied Psychological Measurement, 21, 173-184.

Robinson, B. E. (2000). Workaholism: Bridging the Gap Between Workplace, Sociocultural, and Family Research. Journal of Employment Counseling, 37(1), 31-47. https://doi.org/10.1002/j.2161-1920.2000.tb01024.x

Salovey, P. \& Mayer, J.D. (1990). Emotional Intelligence. Imagination, Cognition and Personality. 9(3), 185-211. https://doi.org/10.2190/DUGGP24E-52WK-6CDG
Savarese, G., Pecoraro, N., Fasano, O., Mollo, M., Iannaccone, A., Manzi, F. \& Curcio, L. (2019). Perceived social support and clinical symptomatology in Italian University students. Global Journal of Guidance and Counseling in Schools: Current Perspectives, 9(3), 90-94. https://doi.org/10.18844/gjgc.v9i3.4121

Schaufeli, W. S. \& Enzmann, D. (1998). The burnout companion to study and practice: a critical analysis. Taylor \& Francis.

Schaufeli, W.B., Taris, T.W. \& Bakker, A. (2006). Dr. Jekyll and Mr. Hide: On the differences between work engagement and workaholism. In R. Burke (Ed.), Research companion to working time and work addiction (pp. 193217). Northampton, MA: Edward Elgar.

Schutte, N. S., Malouff, J. M., Thorsteinsson, E. B., Bhullar, N. \& Rooke, S. E. (2007). A meta-analytic investigation of the relationship between emotional intelligence and health. Personality and Individual Differences, 42(6), 921-933. https://doi.org/10.1016/i.paid.2006.09.003

Seybold, K. C. \& Salomone, P. R. (1994). Understanding workaholism: a review of causes and counseling approaches. Journal of Counseling and Development, 73(1), 4-9. $\quad$ https://doi.org/10.1002/j.15566676.1994.tb01702.x

Shifron, R. \& Reysen, R. R. (2011). Workaholísm: addiction to work. The Journal of Individual Psychology, 67(2): 136-146.

Snir, R. \& Zohar, D. (2008). Workaholism as discretionary time investment at work: an experience-sampling study. Applied Psychology, 57(1), 109127. https://doi.org/10.1111/j.1464-0597.2006.00270.x

Spence, J. T. \& Robbins, A. S. (1992). Workaholism: definition, measurement and preliminary results. Journal of Personality Assessment, 58(1), 160178 .

Sudak, M. K. \& Zehir, C. (2013). Kisilik Tipleri, Duygusal Zeka, Is Tatmini Iliskisi Uzerine Yapılan Bir Arastirma [A study on the relationship between personality traits, emotional intelligence and job satisfaction]. Yonetim Bilimleri Dergisi, 11(22), 141-165.

Tenko Raykov \& George A. Marcoulides (2006) On Multilevel Model Reliability Estimation from the Perspective of Structural Equation Modeling, Structural Equation Modeling, 13:1, 130-141, https://doi.org/10.1207/s15328007sem1301 7

Tozkoparan, G. (2013). Bes Faktor Kisilik Ozelliklerinin Catisma Yonetim Tarzlarina Etkisi: Yoneticiler Uzerinde Bir Arastirma [The effects of five-factor personality traits on conflict management styles: a study on managers]. Ekonomik ve Sosyal Arastrmalar Dergisi, 9(2), 189-231.

Yurtbasi, M. (2018). Correcting English learner's suprasegmental errors. Global Journal of Foreign Language Teaching, 7(4), 126-131. https://doi.org/10.18844/gjflt.v7i4.3000 